\title{
CAN EPHEMEROPTERA, PLECOPTERA, TRICHOPTERA (EPT) ASSEMBLAGES REFLECT NITROGEN AND PHOSPHORUS LOAD IN A RIVERINE ECOSYSTEM?
}

\author{
Lidija Kladarići ${ }^{*}$, Renata Ćuk ${ }^{1}$, Ivor Dukića ${ }^{2}$, \\ Aleksandar Popijač ${ }^{3} \&$ Andrea Marinović Ruždjak ${ }^{1}$
}

\author{
${ }^{1}$ Hrvatske vode, Central Water Management Laboratory, Ulica Grada Vukovara 220, \\ HR-10000 Zagreb, Croatia \\ ${ }^{2}$ student, Faculty of Science in Split, Ruđera Boškovića 33, HR-21000 Split, Croatia \\ ${ }^{3}$ Kopački rit Nature Park Public Institution, Mali Sakadaš 1, 31327 Kopačevo, Bilje, Croatia
}

Kladarić, L., Ćuk, R., Dukić, I., Popijač, A. \& Marinović Ruždjak, A.: Can Ephemeroptera, Plecoptera, Trichoptera (EPT) assemblage reflect nitrogen and phosphorus load in the riverine ecosystem? Nat. Croat., Vol. 30, No. 1, 217-230, Zagreb, 2021.

The aim of this paper is to make a comparative analysis of benthic macroinvertebrate compositions in streams and rivers in Croatia with relation to different physical-chemical factors, especially nutrients. Samples were collected according to the AQEM method. At all the sites, 20 higher taxonomic categories were recorded of which Turbellaria, Gastropoda, Bivalvia, Oligochaeta, Hirudinea, Crustacea, Ephemeroptera, Odonata, Plecoptera, Heteroptera, Trichoptera, Coleoptera and Diptera were included in the present study. Water temperature mostly affected the composition of benthic macroinvertebrates to which it was inversely proportional. Nutrient enrichment, i.e., higher concentrations of ammonium, nitrates, nitrites, total nitrogen, orthophosphates and total phosphorus mostly affected Ephemeroptera, Plecoptera, Trichoptera and Diptera, by decreasing their diversity.

Keywords: nutrient enrichment, water temperature, watercourse, macrozoobenthos, Croatia

Kladarić, L., Ćuk, R., Dukić, I., Popijač, A. \& Marinović Ruždjak, A.: Može li zajednica Ephemeroptera, Plecoptera, Trichoptera (EPT) odraziti opterećenje dušikom i fosforom u riječnom ekosustavu? Nat. Croat., Vol. 30, No. 1, 217-230, Zagreb, 2021.

Cilj ovog rada bio je izvršiti usporednu analizu sastava bentoskih makrobeskralježnjaka u potocima i rijekama u Hrvatskoj u odnosu na različite fizikalno-kemijske čimbenike, posebno hranjive tvari. Uzorci su prikupljeni prema AQEM metodi. Na svim nalazištima zabilježeno je 20 viših taksonomskih kategorija od kojih su u ovo istraživanje uključeni: Turbellaria, Gastropoda, Bivalvia, Oligochaeta, Hirudinea, Crustacea, Ephemeroptera, Odonata, Plecoptera, Heteroptera, Trichoptera, Coleoptera i Diptera. Temperatura vode je najviše utjecala na sastav makrozoobentosa. Što je temperatura vode viša, raznolikost svojti makrozoobentosa je niža. Obogaćivanje hranjivim tvarima, odnosno više koncentracije amonijaka, nitrata, nitrita, ukupnog dušika, ortofosfata i ukupnog fosfora, najviše je utjecalo na Ephemeroptera, Plecoptera, Trichoptera i Diptera, smanjujući njihovu raznolikost.

Ključne riječi: hranjive tvari, temperatura vode, tekućice, vodeni beskralježnjaci, Hrvatska

\footnotetext{
*Author for correspondence (lidija.kladaric@voda.hr)
} 


\section{INTRODUCTION}

Freshwaters are among the most threatened ecosystems globally (VÖRÖSMARTY et al., 2010).

A wide range of human-generated stressors that degrade water quality and hydro-morphology affect life in European rivers. One of the main stressors on river quality is nutrient enrichment, which is the reason for $34.4 \%$ deviance in ecological status, hydro-morphological degradation causes 39.4\% deviance (morphology: 23.2\% and hydrology: $16.2 \%$ ), whereas the rest, $26.2 \%$ of deterioration, is a result of toxic substances (Lemm et al., 2020). The eutrophication and organic pollution of freshwater ecosystems is considered a pan-European problem "of major concern" (DAHL \& JOHNSON, 2004; EEA, 2018).

Agriculture contributes most to nitrogen and phosphorus pollution (FIERRO et al., 2017). Thanks to the EU Nitrates Directive and national measures, nitrogen pollution from agriculture has been reduced in some regions over the last 15-20 years. The reduced pressure is reflected in lower river nitrate concentrations. However, the apparent stabilisation of river nitrate concentrations in recent years may call for further measures to be taken (EEA, 2021).

The average concentration of phosphates in European rivers decreased twice over the period 1992-2012. The decrease in river phosphate concentration can be related to the measures introduced by national and European legislation, in particular the Urban Waste Water Treatment Directive, which involves the removal of nutrients. Also, the change to phosphate-free detergents has contributed to the lower phosphorus concentrations (EEA, 2021).

Aquatic macrophyte and algae quantities are good indicators of nutrient enrichment (CONLEY et al., 2009), as they require several macronutrients for growth (especially nitrogen and phosphorus), and freshwater macroinvertebrates provide good evidence of response to their fluctuations (RADER \& Richardson, 1992; GAFNER \& Robinson, 2007; OuYAng et al., 2018; Everall et al., 2019;).

Anthropogenic pressure, especially nutrient enrichment, has many negative impacts on freshwater organisms (Allan, 2004; Moore \& Palmer, 2005; Riseng et al., 2011; Cur et al., 2017). It has been noticed that nutrient enrichment influences aquatic invertebrates by decreasing their richness (PAUL \& MEYER, 2001), particularly eliminating the sensitive taxa such as Ephemeroptera, Plecoptera and Trichoptera (EPT) (LENAT, 1988).

Although there are increasing numbers of studies on the effects of nutrient enrichment on biota (Alcaraz et al., 1999; Berenzen et al., 2001; LaWrence \& Gresens, 2004; Matthaei et al., 2010; Prater et al., 2015), comparative studies among different macroinvertebrate taxa are scarce.

The object of this study was to present the response of EPT assemblages (i.e., EPT species richness) to nitrate, nitrite, ammonium and orthophosphate concentrations within 71 Croatian streams and rivers. The questions addressed in the study were: (1) which physical-chemical parameters have a significant effect on the EPT assemblage and (2) whether nutrient enrichment has the strongest impact on the EPT assemblage. 


\section{MATERIAL AND METHODS}

\section{Study Area}

The Republic of Croatia lies at the intersection of two ecoregions: Dinaric Western Balkan (ER5) and Hungarian Lowlands (ER11) according to ILLIEs (1978). Considering the geographical location of Croatia and its position within Central Europe and the Mediterranean, as well as climatic and geological conditions, is the country can be divided into the Pannonian and karst parts. Sava, Drava and Danube rivers flow through the lowland Pannonian part. Aquifers of the lowland rivers consist of thick layers of deposited gravel. The karst area is determined by special karst hydro-morphological features formed due to the solubility of the carbonate rocks that make up the terrain. Karst covers approximately half of the total area of the country (ŠAFAREK \& ŠOLIĆ, 2011).

\section{Sampling and laboratory work}

Biological data were obtained as a part of the monitoring and assessment programme conducted by the Central Water Management Laboratory of Hrvatske vode. The samples of benthic macroinvertebrates were taken over a period of 3 years (20152017).

The sampling was conducted in the period of low and stable water levels, mostly in the warm period of the year (spring and summer). In total, 114 samples from 106 sampling stations in 71 Croatian streams and rivers were collected and analysed (Fig. 1).

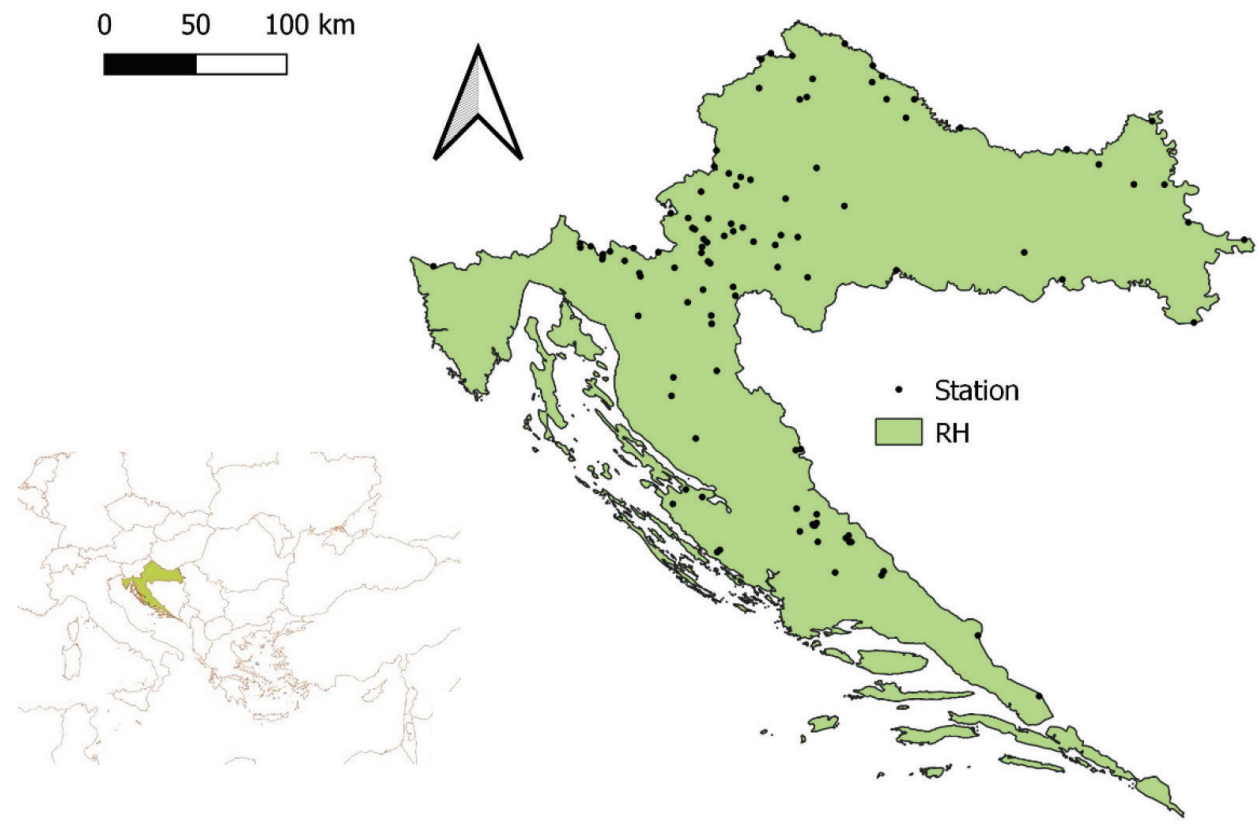

Fig. 1. Map of Croatia with sampling stations (106 sampling stations in 71 Croatian streams and rivers) 
Samples were collected with a hand net $(25 \times 25 \mathrm{~cm}$ aperture and mesh size 500 $\mu \mathrm{m})$ according to the AQEM sampling procedure (AQEM, 2002) in a littoral zone of rivers where 20 quantitative replicative samples were collected $\left(0.0625 \mathrm{~m}^{2}\right)$ from all microhabitats represented by more than $5 \%$. Endangered or protected species were identified in the field and immediately released back into the stream. Macroinvertebrates and associated organic material were immediately placed in plastic bottles and preserved in $80 \%$ ethanol.

Isolation and determination of benthic macroinvertebrates were conducted in the laboratory with the use of a binocular stereomicroscope (Olympus SZX9 and SZX10). The organisms were determined to the lowest possible taxonomic level, usually to species or genus level (with the exception of chironomids and oligochaetes) and separated into the higher taxonomic categories. The result was a list of taxa comprising the number of individuals found in each sample (Official Gazette, 2020; Hrvatske VODE, 2015). At the end, the abundance of the macroinvertebrates was calculated as number of individuals per $\mathrm{m}^{2}$.

In order to perform statistical analysis, higher taxonomic categories represented with a single taxon were excluded from further analyses (Coelenterata, Nematoda, Polychaeta, Araneae, Megaloptera, Lepidoptera and Hydrachnidia).

Standard determination keys were used (KeroveC \& ČIČIn-ŠAIN, 1986; CAmpaIoli et al., 1994; SCHWAB, 1995; Nilsson, 1996; WARINGER \& Graf, 1997; Grabow, 2000; BAuERnFEIND \& Humpesch, 2001; Zwick, 2004; ENGElHARdT et al., 2008). All specimens have been deposited in the macrozoobenthos collection in the Central Water Management Laboratory of Hrvatske vode.

\section{Physical and chemical parameters}

Sampling, preservation and chemical analyses of the water samples were performed according to standard methods for the examination of surface waters (ISO Standards, APHA 1998). Water samples were collected in appropriate containers, kept in the dark at $4^{\circ} \mathrm{C}$ and analysed within $24 \mathrm{~h}$. Selected water quality parameters included water temperature (WT), $\mathrm{pH}$, electrical conductivity (EC), total suspended solids (TSS), m-alkalinity, total water hardness $(\mathrm{dH})$, and concentrations of ammonium, nitrite, nitrate, total nitrogen (TN), orthophosphate (OP) and total phosphorus (TP) (Tab. 1).

WT was measured on-site while $\mathrm{pH}$ and EC were measured either on-site (portable $\mathrm{pH}$ and conductivity meters, HANNA instruments) or in the laboratory (Mettler Toledo SevenMulti dual $\mathrm{pH}$ and conductivity meter). Water samples for the analysis of ammonium, nitrite, nitrate and OP concentrations were field filtered through 0.45 $\mu \mathrm{m}$ cellulose nitrate membrane filter.

Inorganic nitrogen was obtained as the sum of the nitrite, nitrate, and ammonium concentrations while organic nitrogen was calculated by subtracting inorganic nitrogen from the obtained results of TN. TN measurements were performed on a Shimadzu TOC-V/TNM-1.

The ammonium molybdate spectrophotometric method (on Perkin Elmer Lambda 25) was applied for the determination of OP. The TP was determined using acid digestion followed by the molybdate method. Since 2016, TP analyses have been performed on an Agilent 8900 ICP-MS. 
Tab. 1. Descriptive statistics of physical-chemical parameters and nutrients

\begin{tabular}{|c|c|c|c|c|c|}
\hline \multicolumn{2}{|r|}{ Variable } & $\mathrm{n}$ & Mean & Min & Max \\
\hline \multirow{6}{*}{$\begin{array}{l}\text { Physical- } \\
\text { chemical } \\
\text { parameters }\end{array}$} & $\mathrm{WT}\left({ }^{\circ} \mathrm{C}\right)$ & 114 & 12.34 & 7.48 & 24.42 \\
\hline & $\mathrm{pH}$ & 114 & 7.99 & 7.23 & 8.46 \\
\hline & $\mathrm{EC}(\mu \mathrm{S} / \mathrm{cm})$ & 114 & 509.46 & 78.64 & 6199.17 \\
\hline & TSS (mg/L) & 114 & 9.18 & 0.76 & 53.42 \\
\hline & Alkalinity (mgCaCO3/L) & 114 & 193.89 & 30.64 & 387.23 \\
\hline & $\mathrm{dH}(\mathrm{mgCaCO} / \mathrm{L})$ & 114 & 244.85 & 31.53 & 1368.60 \\
\hline \multirow{6}{*}{ Nutrients } & Ammonium (mgN/L) & 114 & 0.11 & 0.00 & 1.78 \\
\hline & Nitrite (mgN/L) & 114 & 0.01 & 0.00 & 0.08 \\
\hline & Nitrate $(\mathrm{mgN} / \mathrm{L})$ & 109 & 0.82 & 0.05 & 3.43 \\
\hline & $\mathrm{TN}(\mathrm{mgN} / \mathrm{L})$ & 114 & 1.91 & 0.28 & 60.06 \\
\hline & $\mathrm{OP}(\mathrm{mgP} / \mathrm{L})$ & 114 & 0.02 & 0.00 & 0.34 \\
\hline & $\mathrm{TP}(\mathrm{mgP} / \mathrm{L})$ & 87 & 0.08 & 0.00 & 0.53 \\
\hline
\end{tabular}

\section{Data analysis}

The number of taxa of higher taxonomic categories found in samples was calculated with the software ASTERICS version 1.0. (AQEM/STAR Ecological River Classification System) for each sampling site. This metric was selected in order to assess the effect of nutrients (ammonium, nitrite, nitrate, TN, OP and TP) on macrozoobenthos diversity.

Box-plots were used to compare the number of taxa among sampling stations, streams and rivers. A correlation analysis was performed to examine the relationship between the number of taxa and physical-chemical parameters, including nutrients. Spearman correlation coefficients were calculated for this purpose. The significance of the Spearman rank-order correlation coefficients was assessed using a two-sided test. Levels of significance were set at $p<0.01$ and $p<0.05$. Finally, principal component analysis was used to reduce the dimensionality of the data and to summarise the variation in the number of taxa and relate it to the environmental variables.

Statistical analysis of the data was carried out using IBM SPSS Statistics Version 24 (IBM Corp., Armonk, NY, USA) and Statistica 12 (StatSoft, Inc., Tulsa, OK, USA). All ordinations were provided by the program CANOCO 5.0 (TER BRAAK \& SMILAUER, 2012).

A principal component analysis (PCA) was conducted on $\log (x+1)$ transformed environmental data (except $\mathrm{pH}$ ). A detrended correspondence analysis (DCA) was performed to determine the gradient length. The choice of PCA was justified, since response data had a gradient 1.8 SD units long. According to the Canoco Advisor expert system, the response variables (number of taxa within the investigated macrozoobenthos higher taxonomic categories) were not transformed. However, given the fact that different taxa from various watercourses and ecoregions were analysed, centralization and standardization were performed. 


\section{RESULTS}

The box-plot diagram suggests that some higher taxonomic categories, like Diptera and Trichoptera are represented by more taxa than other taxonomic categories. There are no extreme variables, but outliers are present (Fig. 2).

Tab. 2 shows the Spearman rank-order correlation coefficients between the number of taxa within individual higher taxonomic categories, and physical-chemical parameters including nutrients. Some taxonomic categories are more strongly correlated with the environmental variables than others. The results imply that higher nutrient concentrations result in lower Ephemeroptera, Plecoptera, Trichoptera and Diptera numbers. Thereby, the highest correlation was obtained with the nitrites and OP (Tab. 2). Trichoptera and Diptera are negatively correlated with TP $(-0.511$ and 0.407, respectively). Some higher correlations were found for ammonium and Plecoptera and Trichoptera (-0.449 and-0.470, respectively) and between EPT and TN $(-0.403,-0.447$ and -0.468 , respectively).

Plecoptera richness was significantly negatively correlated to WT $(-0.491)$. EPT taxa best react to the increase of EC, by reduction of number of species. The results presented in Table 2 also indicate that EPT and Diptera negatively correlated to TSS.

Inorganic nutrients (ammonium, nitrite, nitrate, TN, OP, TP) were positively correlated with richness of some taxonomic categories, e.g., Bivalvia, Gastropoda, Hirudinea, Odonata and Crustacea.

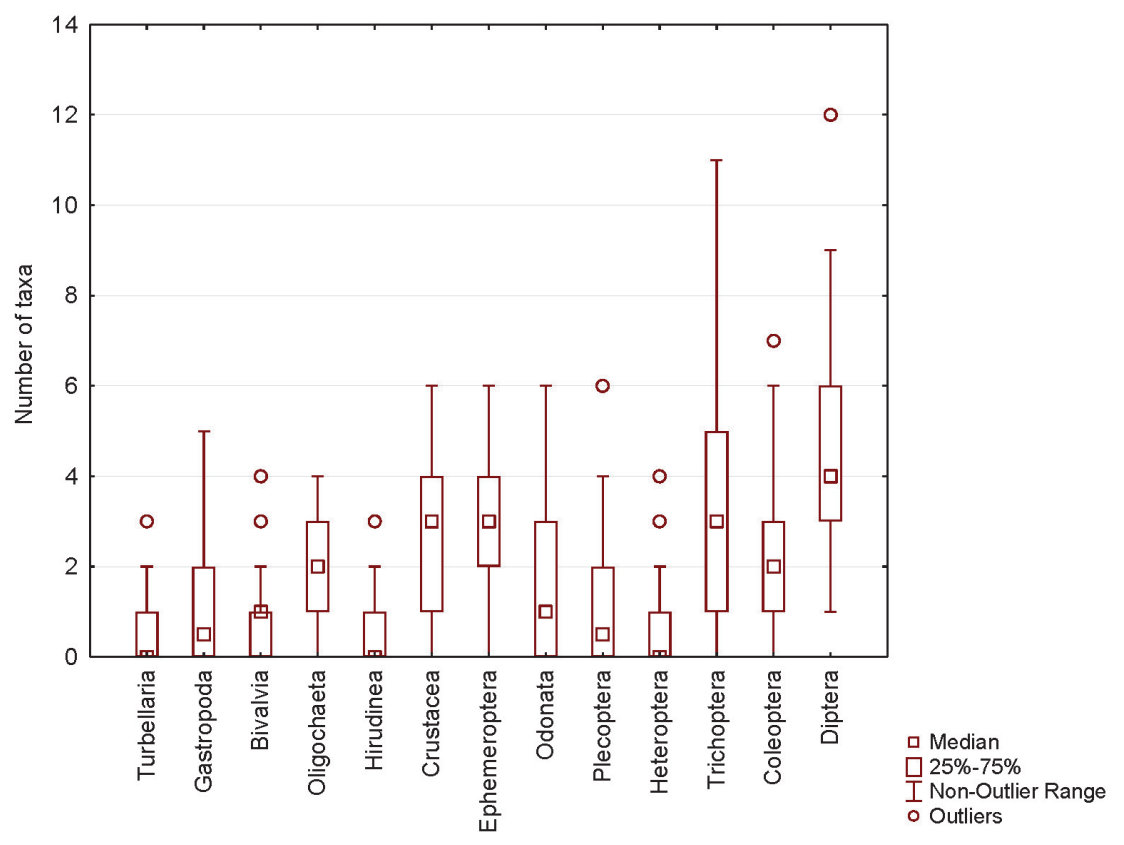

Fig. 2. Box plots of the number of taxa (species, genus) in certain higher taxonomic categories found at 106 sampling stations in 71 streams and rivers 
Tab. 2 Spearman's correlation coefficients between the number of taxa in certain higher taxonomic categories and physical-chemical parameters including nutrients

\begin{tabular}{|c|c|c|c|c|c|c|c|c|c|c|c|c|}
\hline \multirow[b]{2}{*}{ Order } & \multicolumn{6}{|c|}{ Nutrients } & \multicolumn{6}{|c|}{ Physical-chemical parameters } \\
\hline & 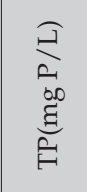 & 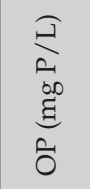 & $\begin{array}{l}\text { త1 } \\
\text { Z } \\
00 \\
\text { E્ } \\
\text { Z }\end{array}$ & 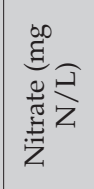 & 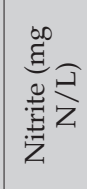 & 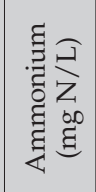 & 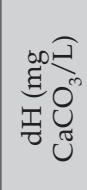 & 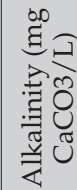 & 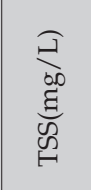 & 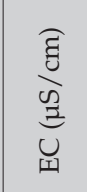 & $\stackrel{T}{2}$ & $\frac{0}{0}$ \\
\hline Turbellaria & -0.163 & -0.175 & $-0.242 * *$ & $-0.208^{*}$ & $-0.319^{* *}$ & $-0.281^{* *}$ & 0.078 & 0.024 & $-0.235^{*}$ & 0.022 & 0.075 & $-0.193^{*}$ \\
\hline Gastropoda & 0.204 & 0.173 & $0.249^{* *}$ & $0.266^{* *}$ & 0.081 & $0.201^{*}$ & -0.155 & -0.122 & 0.120 & -0.132 & 0.134 & $0.324^{* *}$ \\
\hline Bivalvia & 0.179 & $0.232^{*}$ & 0.100 & 0.154 & 0.065 & 0.098 & -0.181 & $-0.201^{*}$ & $0.208^{*}$ & -0.111 & 0.166 & $0.270^{* *}$ \\
\hline Oligochaeta & 0.120 & -0.016 & 0.082 & 0.044 & 0.028 & $0.200^{*}$ & 0.035 & 0.077 & 0.024 & 0.043 & 0.022 & 0.099 \\
\hline Hirudinea & $0.238^{*}$ & $0.232^{*}$ & 0.141 & 0.018 & 0.168 & $0.241^{* *}$ & 0.073 & 0.066 & 0.070 & 0.038 & $-0.203^{*}$ & 0.023 \\
\hline Crustacea & -0.065 & 0.056 & 0.108 & 0.090 & 0.092 & $0.191^{*}$ & 0.046 & 0.037 & -0.025 & 0.089 & -0.155 & $0.362^{* *}$ \\
\hline $\begin{array}{l}\text { Ephe- } \\
\text { meroptera }\end{array}$ & $-0.306^{* *}$ & $-0.415^{* *}$ & $-0.403^{* *}$ & $-0.289^{* *}$ & $-0.568^{* *}$ & $-0.354^{* *}$ & $-0.188^{*}$ & -0.146 & $-0.353^{* *}$ & $-0.291 * *$ & 0.122 & $-0.324^{* *}$ \\
\hline Odonata & 0.127 & 0.177 & $0.211^{*}$ & 0.170 & $0.230^{*}$ & $0.373^{* *}$ & $0.184^{*}$ & $0.214^{*}$ & 0.121 & $0.231^{*}$ & -0.041 & $0.551^{* *}$ \\
\hline Plecoptera & $-0.385^{* *}$ & $-0.490^{* *}$ & $-0.447^{* *}$ & $-0.361^{* *}$ & $-0.476^{* *}$ & $-0.449 * *$ & $-0.186^{*}$ & -0.119 & $-0.443^{* *}$ & $-0.288^{* *}$ & 0.091 & $-0.491^{* *}$ \\
\hline Heteroptera & 0.183 & 0.132 & $0.195^{*}$ & $0.245^{*}$ & 0.151 & 0.100 & -0.039 & -0.044 & $0.197^{*}$ & 0.027 & 0.063 & $0.365^{* *}$ \\
\hline Trichoptera & $-0.511^{* *}$ & $-0.547^{* *}$ & $-0.468^{* *}$ & $-0.401^{* *}$ & $-0.545^{* *}$ & $-0.470^{* *}$ & -0.134 & -0.134 & $-0.468^{* *}$ & $-0.269^{* *}$ & 0.045 & $-0.463^{* *}$ \\
\hline Coleoptera & $-0.226^{*}$ & $-0.233^{*}$ & -0.133 & -0.144 & -0.096 & 0.016 & $0.204^{*}$ & $0.217^{*}$ & $-0.239^{*}$ & 0.109 & $-0.249 * *$ & -0.092 \\
\hline Diptera & $-0.407^{* *}$ & $-0.412^{* *}$ & $-0.396^{* *}$ & $-0.389^{* *}$ & $-0.362^{* *}$ & $-0.280^{* *}$ & 0.098 & 0.096 & $-0.342^{* *}$ & -0.039 & -0.139 & $-0.370^{* *}$ \\
\hline
\end{tabular}

** Correlation is significant at the 0.01 level

* Correlation is significant at the 0.05 level

\section{Principal components analysis}

The first four PCA axes explain $62.55 \%$ of the variance in the data on the number of taxa, with the first component explaining $24.72 \%$ and the second component $18.31 \%$ of the total variance (Tab. 3 ).

According to PCA, Plecoptera was negatively correlated to WT. Ephemeroptera, Trichoptera and Diptera are negative with TSS, TP, ammonium and nitrate. $\mathrm{pH}$ is at least correlated with EPT and Diptera.

The results of the unconstrained ordination (PCA) are presented by a biplot (Fig. 3). The diagram shows the first two PCA axes. In addition to the response variables (number of taxa of higher taxonomic categories (Fig. 2), physical-chemical parameters and nutrients are also presented in the biplot. The first principal component is mostly negatively correlated with environmental variables. The orders like Ephemeroptera, Plecoptera, Trichoptera and Diptera tend to have larger abundance in colder waters with reduced concentrations of TSS, TP, nitrate, nitrite, ammonium and OP. 
Tab. 3. Loadings, eigenvalues, and cumulative explained variation of the first four extracted components

\begin{tabular}{|c|c|c|c|c|}
\hline \multirow{2}{*}{ Higher taxonomic category } & \multicolumn{4}{|c|}{ Component } \\
\cline { 2 - 5 } & 1 & 2 & 3 & 4 \\
\hline Turbellaria & 0.0164 & 0.1439 & 0.7360 & -0.3455 \\
\hline Gastropoda & -0.5674 & 0.4166 & -0.1236 & -0.3465 \\
\hline Bivalvia & -0.4757 & -0.0656 & -0.2306 & -0.6191 \\
\hline Oligochaeta & -0.3710 & 0.4946 & -0.0841 & -0.2127 \\
\hline Hirudinea & -0.4050 & 0.3661 & 0.5714 & -0.0888 \\
\hline Crustacea & -0.5452 & 0.2179 & -0.1565 & -0.0232 \\
\hline Ephemeroptera & 0.4362 & 0.5078 & -0.3825 & -0.2400 \\
\hline Odonata & -0.4978 & 0.4032 & -0.3109 & 0.4044 \\
\hline Plecoptera & 0.8290 & 0.2278 & -0.1619 & -0.1245 \\
\hline Heteroptera & -0.4709 & 0.4388 & -0.0787 & 0.1778 \\
\hline Trichoptera & 0.6841 & 0.5210 & -0.1479 & -0.2465 \\
\hline Coleoptera & 0.0160 & 0.7081 & 0.1662 & 0.4043 \\
\hline Diptera & 0.5009 & 0.5642 & 0.2612 & 0.0842 \\
\hline Eigenvalues & 0.2472 & 0.1831 & 0.1047 & 0.0905 \\
\hline Explained variation (cumulative) & 24.72 & 43.03 & 53.50 & 62.55 \\
\hline
\end{tabular}

\section{DISCUSSION}

According to PCA, the increase of WT is most reflected in the number of taxa of Plecoptera, compared to the other higher taxonomic categories. This is in line with many previous studies (e.g., MEšTrov et al., 1978; Živić et al., 2006; ChinNaYAKANAHALli et al., 2011; KREPSK et al., 2014; STRBAD et al., 2015). Increased temperature generally reduces species richness. Many researchers, who studied water bodies with higher temperature (e.g., post-cooling water from power plant) have found negative effect of temperature to qualitative structure of benthic invertebrate (CiEmiński \& ZDANOwsKi, 2009).

A large proportion of our sampling sites (ca. 50\%) were situated in the Dinaric karst system, and karst rivers are vulnerable to nutrients, particularly nitrates, nitrites and phosphates (PETERSON et al., 2002), due to rapid surface infiltration, anthropogenic activity, and the flow of water through sinkholes and groundwater-influenced river networks (CAETANO BicALHO et al., 2012).

This investigation is in line with numerous previous investigations (SHOKRI et al., 2014; Zhang et al., 2018; Kelly-Quinn et al., 2020; RAWAT et al., 2020; Leitner et al., 2021) showing that samples from the least anthropogenic disturbed sites (i.e., nitrogen and phosphorus enriched watercourses) are characterized by the presence of pollution sensitive EPT species, indicating that these sites are more pristine. Other organisms, in turn, represented by Gastropoda, Bivalvia, Oligochaeta are known to be present in highly enriched environments (ARMENDÁRIZ et al., 2012; WANG et al., 2012; CHASE et al., 2017) as rather insensitive to nitrogen and phosphorus overload, and can stand in moderately and high enriched waters, which is also seen in results (Tab. 2).

As indicated by Spearman correlations (Tab. 2) and PCA analysis (Fig. 3), it seems that nitrogen in water is equally as important as phosphorus in regulating macroin- 


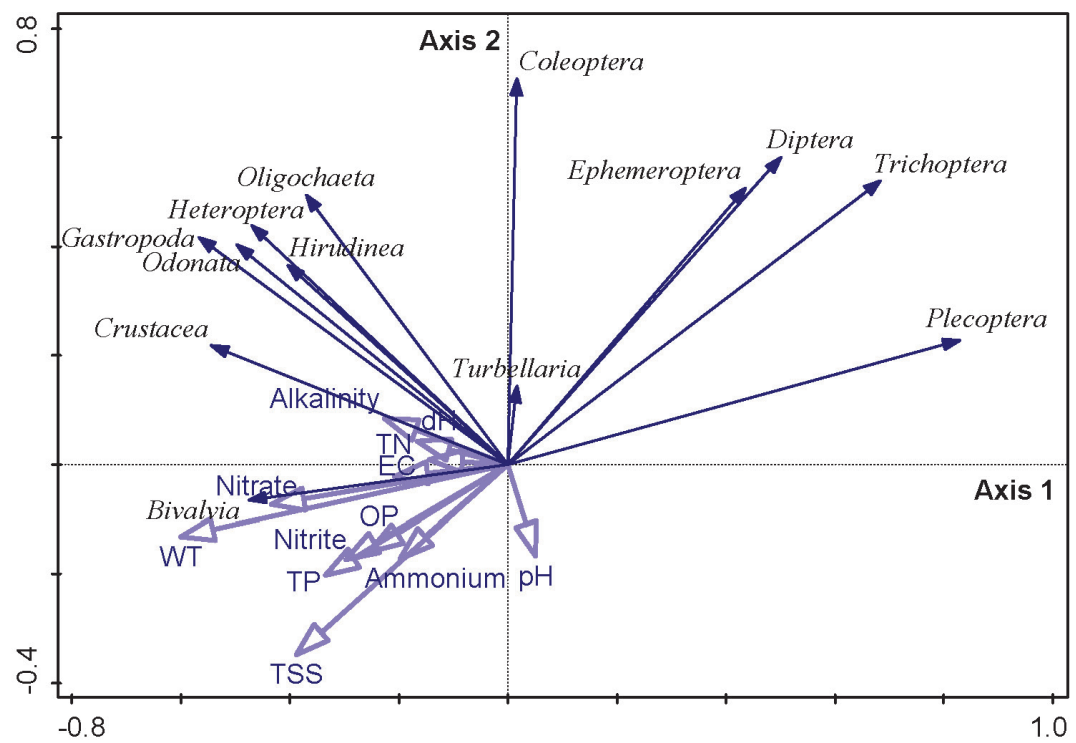

Fig. 3. Ordination of a PCA based on measurements $(n=114)$ of 12 physical and chemical variables at each site during the study. Codes of the variables are given in material and methods. The first two axes of the PCA explain $43.08 \%$ of the total variation (PCA-1: $24.72 \%$, PCA-2: $18.31 \%$ )

vertebrate distribution. The importance of nitrogen as a variable is not surprising as the agriculture in our area uses lot of (1,200,000 t per year) mineral fertilizers (GUGIĆ et al., 2014), which causes an amount of nitrogen leaching to the waterbodies. Intensification of agriculture can lead to soil condition alteration and increase runoff of minerals, which can increase nitrogen amounts in waters (STEFANIDIs et al., 2016). The study of LASSALETTA et al.(2009) concluded that agricultural cover explained $82 \%$ of the variation in nitrite concentration in streams in Ebro River Basin.

National plans to build numerous waste water treatment plants (WWTP) (OFFICIAL GAZETTE, 2020) seems very promising as it will improve water quality by removing nitrogen, phosphorus and their compounds. EEA (2018) reported TP discharges decreased by circa 70\% from 1983 to 2014 in agricultural Germany, mainly due to improved WWTP.

The study revealed many significant correlations between the physical-chemical variables (including nutrients) and macrozoobenthos, but these correlations were relatively weak. Some positive correlation of inorganic nutrients to macrozoobenthos can be explained by functional feeding groups, and their relationship to periphyton which is affected by nutrients (MAKAREwiczet al., 2000; GARG et al., 2009). The collector-gatherer functional feeding group show positive response to nutrient enrichment (Lawrence \& Gresens, 2004). Some previous studies (e.g. Lawrence \& Gresens, 2004) found interesting results in contrast to ours, reporting that Chironomidae (Diptera), especially grazing taxa, showed a strong response to nutrient manipulation. Chironomidae larvae appeared to follow the patterns of increased primary production at phosphorus-enriched sites. In addition, they have a rapid population growth and high densities in nutrient-enriched streams. In impacted aquatic ecosystems, chirono- 
mid assemblages play a key role, particularly in the food web, due to their high densities in impacted ecosystems and rapid population growth (BENKE, 1998; MAASRI et al., 2008).

Benthic invertebrates, especially EPT, respond well to phosphorus enrichment. Development of the DJ multimetric index (DAHL \& JoHnsOn, 2004), showed that EPT was highly correlated to total phosphorus concentration, whether it was the number of EPT taxa, representing richness measures or proportion of EPT taxa, representing composition measures. Perhaps other factors also influence the composition of benthic invertebrates, but they have not been considered in the present study, for example: structure and the composition of the bottom sediments (KERAKOVA \& VARADINOVA, 2020), flow velocity (HaBdja et al., 2004), oxygen content (JACOB et al., 1984; GALIC et al., 2019), heavy metal load (Hirst et al., 2002; STOYANova et al., 2012; Kladarić et al., 2020), hydro-morphological alterations (Urbanič, 2014; Villeneuve et al., 2018; URbanič et al., 2020; ZeLniK \& Muc, 2020).

Further investigations are needed in order to see how nutrient enrichment affects the benthic macroinvertebrate assemblage in the presence of other stressors such as hydromorphological alteration and/or the presence of toxic substances (EEA, 2018; BIRK 2019; POIKANE et al., 2019) to have a better understanding of river status deterioration. It is obvious that individual stressors affect the ecological status of freshwater waterbodies (i.e., water quality) more than a single stressor (GRIZzETTI et al., 2017; REID et al., 2019; Lemm et al., 2020).

\section{CONCLUSIONS}

Among the studied parameters, WT is the best predictor for diversity of freshwater macroinvertebrates.

EPT and Diptera are the most sensitive to nutrient enrichment among all freshwater invertebrates, according to their number of taxa in the sample. A strong negative Spearman correlation coefficient between physical-chemical parameters including nutrient enrichment and EPT implies this interdependence. This confirms the EPT taxa as useful indicators in monitoring stream health, especially nutrient enrichment.

Overall, nutrient levels are the likely cause of variations in diversity and distribution of macroinvertebrates in Croatian streams and rivers. However, future comprehensive analyses are needed to detect the detailed patterns of this interdependence.

Received May 20, 2021

\section{REFERENCES}

Alcaraz, G., Chiappa-Carrara, X., V. E., \& Vanegas, C., 1999: Acute Toxicity of Ammonia and Nitrite to White Shrimp Penaeus setiferus Postlarvae. Journal of the World Aquaculture Society 30(1), 90-97. https://doi.org/10.1111/j.1749-7345.1999.tb00321.x

Allan, D., 2004: Landscapes and Riverscapes: The Influence of Land Use on Stream Ecosystems. Annual Review of Ecology, Evolution, and Systematics 3, 257-284.

Amić, A. \& TAdić, L., 2018: Analysis of Basic Physical-Chemical Parameters, Nutrients and Heavy Metals Content in Surface Water of Small Catchment Area of Karašica and Vučica Rivers in Croatia. Environments 5(2), 1-27. https:/ / doi.org/10.3390/environments5020020 
Armendáriz, L., Ocón, C. \& Rodrigues Capítulo, A., 2012: Potential responses of oligochaetes (Annelida, Clitellata) to global changes: Experimental fertilization in a lowland stream of Argentina (South America). Limnologica 42(2), 118-126. https: / / doi.org/10.1016/j.limno.2011.09.005

APHA (1998) Standard Methods for the Examination of Water and Wastewater. 20th Edition, American Public Health Association, American Water Works Association and Water Environmental Federation, Washington DC.

AQEM., 2002: In Manual for the application of the AQEM method. A comprehensive method to assess European streams using benthic macroinvertebrates, developed for the purpose of the Eater Framework Directive.

Bauernfeind, E. \& Humpesch, U. H., 2001: Die Eintagsfliegen Zentraleuropas (Insecta: Ephemeroptera): Bestimmung und Ökologie. Verl. des Naturhistorischen Museums.

Benke, A. C., 1998: Production dynamics of riverine Chironomids: Extremely high biomass turnover rates of primary consumers. Ecology 79(3), 899-910. https://doi.org/10.1890/0012-9658(1998)079[0899:PDORCE]2.0.CO;2

Berenzen, N., Schulz, R. \& Liess, M., 2001: Effects of chronic ammonium and nitrite contamination on the macroinvertebrate community in running water microcosms. Water Research 35(14), 34783482. https:/ / doi.org/10.1016/S0043-1354(01)00055-0

BIRk, S., 2019: Detecting and Quantifying the Impact of Multiple Stress on River Ecosystems. In: Sabater, S., Ludwig, R., Elosegi, A. (Eds.), Multiple Stressors in River Ecosystems. Elsevier, pp. 235-253.

Caetano Bicalho, C., Batiot-Guilhe, C., Seidel, J. L., Van Exter, S. \& Jourde, H., 2012: Geochemical evidence of water source characterization and hydrodynamic responses in a karst aquifer. Journal of Hydrology, 450-451, 206-218. https: / / doi.org/10.1016/j.jhydrol.2012.04.059

Campaioli, S., Ghetti, P. F., Minelli, A. \& Ruffo, S., 1994: Manuale per il riconoscimento dei macroinvertebrati delle acque dolci italiane (Vol. 1). Provincia autonoma di Trento. https:/ /books.google. $\mathrm{hr} /$ books?id=2lqDwgEACAAJ

Chase, J. W., Benoy, G. A. \& Culp, J. M., 2017: Combined effects of nutrient enrichment and inorganic sedimentation on benthic biota in an experimental stream system. Water Quality Research Journal 52(3), 151-165. https://doi.org/10.2166/wqri.2017.038

Chinnayakanahalli, K. J., Hawkins, C. P., Tarboton, D. G. \& Hill, R. A., 2011: Natural flow regime, temperature and the composition and richness of invertebrate assemblages in streams of the western United States: Macroinvertebrates and stream flow regimes. Freshwater Biology 56(7), 1248-1265. https:/ /doi.org/10.1111/j.1365-2427.2010.02560.x

Ciemiński, J. \& Zdanowski, B., 2009: Changes in the zoobenthos structure in a system of heated lakes in central Poland. Archives of Polish Fisheries 17(4), 221-238. https://doi.org/10.2478/v10086009-0016-x

Conley, D. J., Paerl, H. W., Howarth, R. W., Boesch, D. F., Seitzinger, S. P., Havens, K. E., LanceLOT, C. \& Likens, G. E., 2009: Controlling Eutrophication: Nitrogen and Phosphorus. Science 323, 1014-1015.

Cui, N., Wu, J., Dai, Y., Li, Z. \& Cheng, S., 2017: Influence of nitrogen loading and flooding on seedling emergence and recruitment from a seed bank in Chaohu Lake Basin, China. Environmental Science and Pollution Research 24(28), 22688-22697. https://doi.org/10.1007/s11356-017-9926-0

DAhl, J. \& Johnson, R. K., 2004: A multimetric macroinvertebrate index for detecting organic pollution of streams in southern Sweden. Archiv Für Hydrobiologie 160(4), 487-513. https://doi.org/10.1127/0003-9136/2004/0160-0487

Engelhardt, W., Martin, P., Rehfeldt, K. \& Pfadenhauer, J., 2008: Was lebt in Tümpel, Bach und Weiher? Pflanzen und Tiere unserer Gewässer (16., vollst. überarb. Aufl). Franckh-Kosmos.

European Environment Agency, 2018: European waters: Assessment of status and pressures 2018. Publications Office. https://data.europa.eu/doi/10.2800/303664

European Environment Agency, 2021: Water and agriculture: Towards sustainable solutions. Publications Office. https:/ / data.europa.eu/doi/10.2800/73735

Everall, N. C., Johnson, M. F., Wood, P., Paisley, M. F., TrigG, D. J. \& Farmer, A., 2019: Macroinvertebrate community structure as an indicator of phosphorus enrichment in rivers. Ecological Indicators 107, 105619. https:/ / doi.org/10.1016/j.ecolind.2019.105619

Fierro, P., Bertrán, C., Tapia, J., Hauenstein, E., Peña-Cortés, F., Vergara, C., Cerna, C. \& VarGas-Chacoff, L., 2017: Effects of local land-use on riparian vegetation, water quality, and the 
functional organization of macroinvertebrate assemblages. Science of The Total Environment 609, 724-734. https://doi.org/10.1016/j.scitotenv.2017.07.197

GAFNeR, K. \& Robinson, C. T., 2007: Nutrient enrichment influences the responses of stream macroinvertebrates to disturbance. Journal of the North American Benthological Society 26(1), 92-102. https://doi.org/10.1899/0887-3593(2007)26[92:NEITRO]2.0.CO;2

Galic, N., Hawkins, T. \& Forbes, V. E., 2019: Adverse impacts of hypoxia on aquatic invertebrates: A meta-analysis. Science of The Total Environment 652, 736-743. https://doi.org/10.1016/j.scitotenv.2018.10.225

GARG, R. K., RAO, R. J. \& SAKSENA, D. N., 2009: Correlation of molluscan diversity with physico- chemical characteristics of water of Ramsagar reservoir, India. International Journal of Biodiversity and Conservation 1(6), 202-207.

Grabow, K., 2000: Farbatlas Süßwasserfauna: Wirbellose. Ulmer.

Grizzetti, B., Pistocchi, A., Liguete, C., Udias, A., Bouraoui, F. \& van de Bund, W., 2017: Human pressures and ecological status of European rivers. Scientific Reports 7(1), 205. https://doi. org /10.1038/s41598-017-00324-3

Gugić, J., Duvančić, M., Šuste, M., Grgić, I. \& Didak, S., 2014: Proizvodnja i potrošnja gnojiva u Republici Hrvatskoj. Agroeconomica Croatica 4(1), 32-39.

Habdija, I., Habdja, B. P., Matoničkin, R., Kučinić, M., Radanović, I., Milišs, M. \& Mihaljević, Z., 2004: Current velocity and food supply as factors affecting the composition of macroinvertebrates in bryophyte habitats in karst running water. Biologia 59(5), 577-593.

Hirst, H., Juttner, I. \& Ormerod, S. J. , 2002: Comparing the responses of diatoms and macro- invertebrates to metals in upland streams of Wales and Cornwall. Freshwater Biology 47(9), 1752-1765. https://doi.org/10.1046/j.1365-2427.2002.00904.x

HrVATSke vode, 2015: Metodologija uzorkovanja, laboratorijskih analiza i određivanja omjera ekološke kakvoće bioloških elemenata kakvoće

IlLIES, J., 1978:Limnofauna Europaea-Eine Zusammenstellung aller die europaeischen Binnengewaesser bewohnenden mehrzelligen Tierarten mit Angaben über ihre Verbreitung und Ökologie. Gustav Fischer Verrlag.

Jaсов, U., Walther, H. \& Klenke, R., 1984: Aquatic insect larvae as indicators of limiting minimal contents of dissolved oxygen - part II. Aquatic Insects 6(3), 185-190. https://doi. org $/ 10.1080 / 01650428409361183$

Kelly-Quinn, M., Feeley, H. \& Bradley, C., 2020: Status of freshwater invertebrate biodiversity in Ireland's rivers - time to take stock. Biology and Environment: Proceedings of the Royal Irish Academy 120B(2), 65-82. https:/ / doi.org/10.3318/bioe.2020.09

Kerakova, M. \& Varadinova, E., 2020: Influence of the River Bottom Substrate and Sediment Organic Component on the Macrozoobenthos Functional Feeding Groups. 'Prof. Marin Drinov' Publishing House of Bulgarian Academy of Sciences. https://doi.org/10.7546/CRABS.2020.01.08

Kerovec, M. \& C̆ıČın-ŠAin, L., 1986: Priručnik za upoznavanje beskralješnjaka naših potoka i rijeka. SNL.

Kladarić, L., Dukić, I., Ćuk, R., Maldini, K., Milović, S. \& Popijač, A., 2020: Utjecaj fizikalno-kemijskih pokazatelja i metala na zajednicu vodencvjetova, obalčara i tulara (EPT). Hrvatske vode 28(114), 291-300.

Krepski, T., Pilecka-Rapacz, M., Czerniawski, R. \& Domagała, J., 2014: Analysis of benthic macroinvertebrate communities from the Lower sections of Large river in relation to different environmental factors. Open Life Sciences 9(11), 1037-1047. https://doi.org/10.2478/s11535-014-0346-6

Lassaletta, L., García-Gómez, H., Gimeno, B. S. \& Rovira, J. V., 2009: Agriculture-induced increase in nitrate concentrations in stream waters of a large Mediterranean catchment over 25years (19812005). Science of the Total Environment 407, 6034-6043.

Lawrence, J. M. \& Gresens, S. E., 2004: Foodweb Response to Nutrient Enrichment in Rural and Urban Streams. Journal of Freshwater Ecology 19(3), 375-385. https://doi.org/10.1080/02705060. 2004.9664910

Leitner, P., Borghardt, F., Birk, S. \& Graf, W, 2021: Multiple stressor effects on benthic macroinvertebrates in very large European rivers - A typology-based evaluation of faunal responses as a basis for future bioassessment. Science of The Total Environment 756, 1-11. https://doi.org/10.1016/j.scitotenv.2020.143472 
Lemm, J. U., Venohr, M., Globevnik, L., Stefanidis, K., Panagopoulos, Y., van Gils, J., Posthuma, L., Kristensen, P., Feld, C. K., Mahnkopf, J., Hering, D. \& Birk, S., 2020: Multiple stressors determine river ecological status at the European scale: Towards an integrated understanding of river status deterioration. Global Change Biology, gcb.15504. https://doi.org/10.1111/gcb.15504

Lenat, D. R., 1988: Water Quality Assessment of Streams Using a Qualitative Collection Method for Benthic Macroinvertebrates. Journal of the North American Benthological Society 7(3), 222-233. https:/ / doi.org/10.2307/1467422

Maasri, A., Fayolle, S., Gandouin, E., Garnier, R. \& Franquet, E., 2008: Epilithic chironomid larvae and water enrichment: Is larval distribution explained by epilithon quantity or quality? Journal of the North American Benthological Society 27(1), 38-51. https:/ / doi.org/10.1899/07-013R1.1

Makarewicz, J. C., Bertram, P. \& Lewis, T. W., 2000: Chemistry of the Offshore Surface Waters of Lake Erie: Pre- and Post-Dreissena Introduction (1983-1993). Journal of Great Lakes Research 26(1), 82-93. https:/ / doi.org/10.1016/S0380-1330(00)70675-7

Matthaei, C. D., Piggott, J. J. \& Townsend, C. R., 2010: Multiple stressors in agricultural streams: Interactions among sediment addition, nutrient enrichment and water abstraction: Sediment, nutrients \& water abstraction. Journal of Applied Ecology 47(3), 639-649. https: / / doi.org/10.1111/ j.1365-2664.2010.01809.x

Meštrov, M., Krkač, N., Kerovec, M., Lui, A., Lattinger-Penko, R., TavČar, V. \& Žnidarič, D., 1978 : Effects of temperature on dominant macrozoobenthos species of the River Sava under laboratory conditions. SIL Proceedings, 1922-2010 20(3), 1910-1914. https:/ /doi.org/10.1080/03680770.1977. 11896791

Moore, A. A. \& Palmer, M. A., 2005: Invertebrate biodiversity in agricultural and urban headwater streams: Implications for conservation and management. Ecological Applications 15(4), 1169-1177. https:/ / doi.org/10.1890/04-1484

Nilsson, A. (Ed.)., 1996: Ephemeroptera, Plecoptera, Heteroptera, Neuroptera, Megaloptera, Coleoptera, Trichoptera, Lepidoptera. Apollo Books.

Official Gazette, 2019: Regulation on Water Quality Standard, Official Gazette of the Republic of Croatia No. 96/2019.

Official Gazette, 2020: Regulation on the limitation of emissions of waste water, Official Gazette of the Republic of Croatia No. 66/2020

Ouyang, Z., Qian, S. S., Becker, R. \& Chen, J., 2018: The effects of nutrients on stream invertebrates: A regional estimation by generalized propensity score. Ecological Processes 7(1), 21. https://doi. org/10.1186/s13717-018-0132-x

Paul, M. J. \& Meyer, J. L., 2001: Streams in the Urban Landscape. Annual Review of Ecology and Systematics 3, 333-365.

Peterson, E. W., Davis, R. K., Brahana, J. V. \& Orndorff, H. A., 2002: Movement of nitrate through regolith covered karst terrane, northwest Arkansas. Journal of Hydrology 256(1-2), 35-47. https://doi.org/10.1016/S0022-1694(01)00525-X

Poikane, S., Phillips, G., Birk, S., Free, G., Kelly, M. G. \& Willby, N. J., 2019: Deriving nutrient criteria to support 'good' ecological status in European lakes: An empirically based approach to linking ecology and management. Science of The Total Environment 650, 2074-2084. https: / / doi.org/10.1016/j.scitotenv.2018.09.350

Prater, C., Norman, E. J. \& Evans-White, M. A., 2015: Relationships among nutrient enrichment, detritus quality and quantity, and large-bodied shredding insect community structure. Hydrobiologia 753(1), 219-232. https:/ / doi.org/10.1007/s10750-015-2208-2

RADER, R. B. \& RichARDSON, C. J., 1992: The effects of nutrient enrichment on algae and macroinvertebrates in the everglades: A review. Wetlands 12(2), 121-135. https: / / doi.org/10.1007/BF03160593

Rawat, A., Gulati, G., Maithani, R., Sathyakumar, S. \& Uniyal, V. P., 2020: Bioassessment of Mandakini River with the help of aquatic macroinvertebrates in the vicinity of Kedarnath Wildlife Sanctuary. Applied Water Science 10(1), 36. https:/ / doi.org/10.1007/s13201-019-1115-5

Reid, A. J., Carlson, A. K., Creed, I. F., Eliason, E. J., Gell, P. A., Johnson, P. T. J., Kidd, K. A., MacCormack, T. J., Olden, J. D., Ormerod, S. J., Smol, J. P., Taylor, W. W., Tockner, K., Vermaire, J. C., Dudgeon, D. \& Cooke, S. J., 2019: Emerging threats and persistent conservation challenges for freshwater biodiversity. Biological Reviews 94(3), 849-873. https:/ / doi.org/10.1111/brv.12480 
Riseng, C. M., Wiley, M. J., Black, R. W. \& Munn, M. D., 2011: Impacts of agricultural land use on biological integrity: A causal analysis. Ecological Applications 21(8), 3128-3146. https://doi. org/10.1890/11-0077.1

Š́farek, G. \& Šolić, T., 2011: Rijeke Hrvatske. Veda.

Schwab, H. (Ed.), 1995: Süßwassertiere: Ein ökologisches Bestimmungsbuch (1. Aufl., 5. Dr). Klett.

Shokri, M., Rossaro, B. \& Rahmani, H., 2014: Response of macroinvertebrate communities to anthropogenic pressures in Tajan River (Iran). Biologia 69(10), 1395-1409. https://doi.org/10.2478/ s11756-014-0448-7

Stefanidis, K., Panagopoulos, Y. \& Mimikou, M., 2016: Impact assessment of agricultural driven stressors on benthic macroinvertebrates using simulated data. Science of The Total Environment 540, 32-42. https:// doi.org/10.1016/j.scitotenv.2015.08.015

Stoyanova, T., Traykov, I., Yaneva, I. \& Bogoev, V., 2012: Accumulation of Heavy Metals in the Macrozoobenthos of the Luda River, Bulgaria. Biotechnology \& Biotechnological Equipment 26(3), 2981-2986. https://doi.org/10.5504/BBEQ.2012.0027

Strbad, I., Mičetić Stanković, V., Rašan M. \& Kučinić M., 2015: Anthropogenic impact on benthic macroinvertebrate diversity in the middle reach of Drava River and the accompanying gravel pits In: Klobučar, G., Kopjar, N., Gligora Udovič, M., Lukša, Ž., Jelić, D. (eds.) Book of abstracts of the 12th Croatian Biological Congress with International Participation; Zagreb: Hrvatsko biološko društvo 1885. p. 243-244

ter Braak, C. J. F. \& Smilauer, P., 2012: Canoco reference manual and user's guide software for ordination, version 5.0. Microcomputer Power.

URBANIČ, G., 2014: Hydromorphological degradation impact on benthic invertebrates in large rivers in Slovenia. Hydrobiologia 729(1), 191-207. https://doi.org/10.1007/s10750-012-1430-4

Urbanič, G., Mihaljević, Z., Petrovska, V. \& Pavlin Urbanič, M., 2020: Disentangling the Effects of Multiple Stressors on Large Rivers Using Benthic Invertebrates-A Study of Southeastern European Large Rivers with Implications for Management. Water 12(3), 621. https://doi.org/10.3390/ w12030621

Villeneuve, B., Piffady, J., Valette, L., Souchon, Y. \& Usseglio-Polatera, P., 2018: Direct and indirect effects of multiple stressors on stream invertebrates across watershed, reach and site scales: A structural equation modelling better informing on hydromorphological impacts. Science of The Total Environment 612, 660-671. https:/ / doi.org/10.1016/j.scitotenv.2017.08.197

Vörösmarty, C. J., McIntyre, P. B., Gessner, M. O., Dudgeon, D., Prusevich, A., Green, P., Glidden, S., Bunn, S. E., Sullivan, C. A., Liermann, C. R. \& Davies, P. M., 2010: Global threats to human water security and river biodiversity. Nature 467(7315), 555-561. https://doi.org/10.1038/ nature 09440

Wang, B., Liu, D., Liu, S., Zhang, Y., Lu, D. \& Wang, L., 2012: Impacts of urbanization on stream habitats and macroinvertebrate communities in the tributaries of Qiangtang River, China. Hydrobiologia 680(1), 39-51. https://doi.org/10.1007/s10750-011-0899-6

WARINGER, J. \& GRAF, W., 1997: Atlas der österreichischen Köcherfliegenlarven: Unter Einschluss der angrenzenden Gebiete. Facultas Universitätsverlag.

Zelnik, I. \& Muc, T., 2020: Relationship between Environmental Conditions and Structure of Macroinvertebrate Community in a Hydromorphologically Altered Pre-Alpine River. Water 12(11), 2987. https:/ / doi.org/10.3390/w12112987

Zhang, Y., Cheng, L., Tolonen, K. E., Yin, H., GaO, J., Zhang, Z., Li, K. \& Cai, Y., 2018: Substrate degradation and nutrient enrichment structuring macroinvertebrate assemblages in agriculturally dominated Lake Chaohu Basins, China. Science of The Total Environment 627, 57-66. https:// doi.org/10.1016/j.scitotenv.2018.01.232

Zwick, P., 2004: A key to the West Palaearctic genera of stoneflies (Plecoptera) in the larval stage. Limnologica 34(4), 315-348. https:// doi.org/10.1016/S0075-9511(04)80004-5

Živić, I., Marković, Z. \& Brajković, M., 2006: Influence of the temperature regime on the composition of the macrozoobenthos community in a thermal brook in Serbia. Biologia 61(2), 179-191. https://doi.org/10.2478/s11756-006-0029-5 